\title{
Evaluation of the Corrosion Resistance of Some Coating Obtained by Thermal Spray in Plasma Jet, on the Surface of Some Crankshafts Made of C45 Steel
}

\author{
GEORGE MAHU1, CORNELIU MUNTEANU ${ }^{1 *}$, BOGDAN ISTRATE ${ }^{2 *}$, IGOR BLANARI ${ }^{1}$, \\ CORNELIA PALEU ${ }^{1}$, COSMIN MIHAI COTRUT ${ }^{3}$ \\ 1 "Gheorghe Asachi" Technical University of Iasi, Faculty of Mechanical Engineering, 67 Profesor Dimitrie Mangeron Blvd., \\ 67, 700050, Iasi, Romania \\ 2 "Gheorghe Asachi" Technical University of Iasi, Faculty of Materials Science and Engineering, 67 Profesor Dimitrie \\ ${ }^{3}$ University Politehnica of Bucharest, 313 Splaiul Independenţei, 060042, Bucharest, Romania
}

\begin{abstract}
For modern engines the oil change interval can reach up to 30,000 $\mathrm{km}$. If the oils lose their properties and are contaminated, they can adversely affect the corrosion resistance, the surface of the main bearing journals and the main journals of the crankshafts. In this study, the results obtained from the corrosion process were analyzed, in a solution of $3.5 \% \mathrm{NaCl}$ of the layers obtained after spraying the surface of a C45 steel, used in the construction of crankshafts, with three powders: $\mathrm{Cr}_{3} \mathrm{C}_{2}-(\mathrm{Ni2OCr})$, $\mathrm{Al}_{2} \mathrm{O}_{3}-13 \mathrm{TiO}_{2}, \mathrm{Cr}_{2} \mathrm{O}_{3}-\mathrm{SiO}_{2}-\mathrm{TiO}_{2}$. The corrosion process was determined by the potentiodynamic polarization technique. The variations in time of the open-circuit potential and the Tafel curves were analyzed, for the samples with deposited layers and the basic material. Morphology and characterization of the structure of the layers after corrosion were performed by means of SEM microscopy and EDAX analysis. The results confirm that the powders sprayed by the atmospheric plasma spray method protect the surface of C45 steel from corrosion.
\end{abstract}

Keywords: corrosion, thermal spray, plasma, C45 steel

\section{Introduction}

In the automotive industry, crankshafts are one of the most requested components of the internal combustion engine. To increase the wear resistance of crankshafts, heat treatments are applied on the surface of the main bearing journals and the main journals to harden them. The most common treatments are: nitriding, carburising, chromium plating, carbonitriding etc [1]. According to the current trends, a new methodology for the modification of the surface quality is developed: thermal spray process. The most common process of thermal spray coating is the process of plasma jet deposition (APS) [2]. By using the APS method to cover various surfaces (including steel parts), the wear resistance, high temperatures and corrosion can be improved. Also the coatings ensure an increase of the surface hardness and reduced porosity, this having a positive effect on the corrosion resistance [3-11].

There have been studies on the deposition of powders by the APS method, which have highlighted the increased hardness and rigidity of the layers, but also that the coatings obtained by this method are very adherent even without a coating, having a good resistance under the conditions. high temperature even if they have a small layer thickness [12-16]. The oils used for modern engines have an exchange range that can reach $30000 \mathrm{~km}$. Although the range is flexible, the oil can be contaminated with fuels, especially during cold starts, when a small amount of fuel can reach the oil, thus affecting the viscosity, the ignition point and the flow point [17-20].

Tsuchiya et al. conducted a study on current fuels which shows that a minimum of $2 \%$ biodiesel in fuel composition can lead to premature wear of metal components [21]. In the case of diesel engines, the regeneration of the particulate filter can lead to the dilution of the oil, the consequences being the ones presented above $[22,23]$. The main engine oil degradation processes are oxidation, chemical changes

*email:cornelmun@gmail.com, bogdan.istrate1@yahoo.com 
caused by thermal processes, corrosion, mechanical decomposition and contamination. The corrosion occurs due to the influence of the acid components resulting from the formation of hydrogen ions $(\mathrm{H}+)$ [24]. The steel components without surface treatment are affected by corrosion, the roughness of the surfaces having an important role in the way the parts are affected [25].

The corrosion rate depends on a number of factors that influence the kinetics of the mechanisms in the case of several processes involved in the transport of ions from metal to solution and in cathodic reactions [26]. In some cases, corrosion may affect metal parts (especially main bearings), as compared to the wear caused by oil degradation, laboratory tests confirming the data obtained from dynamic bench tests [27].

Rostek and Babiak conducted a research on the degradation of lubricant parameters in extended range oil change machines. The study concludes that the temperatures reached by the oil in normal operation, lead in the long term to the progressive degradation of the oxidation inhibitors, this causing the change of viscosity along with the increase of the acidity value, so that the danger of corrosion in the bearings and the piston segments appears [28].

The purpose of this study is to determine the corrosion resistance of the layers deposited by the method of plasma jet coating method on the surface of some crankshafts.

\section{Materials and methods}

\subsection{Methodology}

The powders used in the thermal spraying process were selected based on the information provided by the manufacturer (Oerlikon Metco). The characteristics of the powders are presented in Table 1.

Table 1. Characteristics of the selected powders

\begin{tabular}{|c|c|c|c|c|}
\hline Powder & $\begin{array}{c}\text { Chemical } \\
\text { composition }\end{array}$ & Particle size $(\mu \mathrm{m})$ & Density $\left(\mathrm{g} / \mathrm{cm}^{3}\right)$ & $\begin{array}{l}\text { Maximum service } \\
\text { temperature }\left({ }^{\circ} \mathbf{C}\right)\end{array}$ \\
\hline Metco 130 & $\mathrm{Al}_{2} \mathrm{O}_{3} 13 \mathrm{TiO}_{2}$ & $53+15$ & 3.5 & 540 \\
\hline Metco 81NS & $\mathrm{Cr}_{3} \mathrm{C}_{2}(\mathrm{Ni} 20 \mathrm{Cr})$ & $106+10$ & 5.9 & 870 \\
\hline Metco $136 \mathrm{~F}$ & $\mathrm{Cr}_{2} \mathrm{O}_{3} \mathrm{SiO}_{2} \mathrm{TiO}_{2}$ & $53+15$ & 4.9 & 540 \\
\hline
\end{tabular}

Powders were sprayed on the test surface using the SPRAYWIZARD-9MCE purchased from Sulzer Metco, their appearance being shown in Figure 1. Table 2 presents the technological parameters used to deposit the selected powders. No intermediate layer was used, for the applications designed in this study, without this type of coating, the manufacturer recommends only the preparation of the spray surface preheated at $100^{\circ} \mathrm{C}[29-31]$.

Table 2. Spray parameters used for deposited powders

\begin{tabular}{|c|c|c|c|}
\hline \multirow[b]{2}{*}{ Technological parameters } & \multicolumn{3}{|c|}{ Powder } \\
\hline & $\mathrm{Al}_{2} \mathrm{O}_{3} 13 \mathrm{TiO}_{2}$ & $\mathrm{Cr}_{3} \mathrm{C}_{2}(\mathrm{Ni20Cr})$ & $\mathrm{Cr}_{2} \mathrm{O}_{3} \mathrm{SiO}_{2} \mathrm{TiO}_{2}$ \\
\hline Spray distance (mm) & 100 & 100 & 64 \\
\hline Injector (mm) & 1.8 & 1.8 & 1.8 \\
\hline Plasma gas intensity, (A) & 500 & 500 & 500 \\
\hline Electric arc voltage $(\mathrm{V})$ & 65 & 64 & 64 \\
\hline Argon flow (mºh) & 4.8 & 4.8 & 4.8 \\
\hline Hydrogen flow $\left(\mathrm{m}^{3} / \mathrm{h}\right)$ & 1.5 & 0.9 & 0.9 \\
\hline Argon pressure (bar) & 6.89 & 6.89 & 5.17 \\
\hline Hydrogen pressure (bar) & 3.45 & 3.45 & 3.45 \\
\hline
\end{tabular}




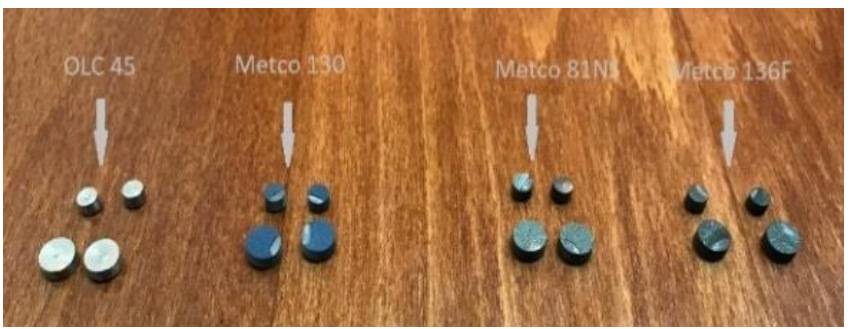

Figure 1. The samples for electrochemical corrosion, after spraying

The corrosion resistance was determined by potentiodynamic polarization technique. This consists in plotting the linear polarization curves involving the following steps:

- measuring / monitoring the open circuit potential (EOC), for a duration of $3 \mathrm{~h}$;

- drawing the curves of potentiodynamic polarization from $-200 \mathrm{mV}$ (vs OCP) to $+200 \mathrm{mV}$ (vs OCP) - Tafel curves, with a scan rate of $0.167 \mathrm{mV} / \mathrm{s}$.

Corrosion resistance tests were performed using a potentiostat / galvanostat (model PARSTAT 4000, Princeton Applied Research) to which a low current module (VersaSTAT LC) was coupled, and the potentiodynamic curves (Tafel) were processed using VersaStudio software. For the tests, a corrosion cell comprising a saturated calomel electrode (SCE) - reference electrode, a platinum electrode as counter electrode and the working electrode, which consisted of the experimental samples to be investigated, was used. The electrochemical cell was inserted, during the corrosion tests, into a Faraday cage in order to eliminate the interference due to the electromagnetic fields. The tests were carried out at $25 \pm 1{ }^{\circ} \mathrm{C}$, using as electrolyte a $3.5 \% \mathrm{NaCl}$ solution. The tested samples were coded in the corrosion resistance tests according to the data presented in Table 3.

Table 3. Codification of samples subjected to electrochemical corrosion tests

\begin{tabular}{|c|c|c|}
\hline 1. & C45 Steel & C45 \\
\hline 2. & C45 coated steel with Metco 81NS & M81NS \\
\hline 3. & C45 coated steel with Metco 130 & M130 \\
\hline 4. & C45 coated steel with Metco 136F & M136F \\
\hline
\end{tabular}

The observations and images of the analyzed microstructures were made with the help of the Quanta 200 3D Dual Beam electron microscope (FEI), equipped with the semi-quantitative elemental chemical analysis module (EDS, energy dispersive X ray spectroscopy) produced by EDAX - Ametek. Because the analyzed coatings belong to the category of ceramic and ceramic - metal coatings, for the electron microscopy the Low Vacuum working module was chosen, with LFD (Large Field Detector) specific detector, the images being acquired at magnification powers between 500x and 5000x.

\section{Results and discussions}

Following the corrosion tests carried out in $3.5 \% \mathrm{NaCl}$ solution, the following parameters characterizing the corrosion resistance of the investigated samples were determined: open circuit potential (Eoc), corrosion potential (Ecor), density of corrosion current (icor), slope of the cathode curve $(\beta c)$, slope of the anodic curve $(\beta a)$. Based on the parameters determined from the Tafel curves (Figure 3 ), the following parameters were also calculated using the corrosion resistance of the investigated samples can be characterized:

-polarization resistance $(\mathrm{Rp})$,

-the porosity of the layers $(\mathrm{P})$,

-efficiency in corrosive attack $(\mathrm{Pe})$. 
The polarization resistance was calculated according to ASTM G59-97 (2014) using the Stern-Geary equation:

where:

$$
R_{p}=\frac{1}{2.3} \frac{\beta_{a}\left|\beta_{c}\right|}{\left(\beta_{a}+\left|\beta_{c}\right|\right)} \frac{1}{i_{c o r}}
$$

$\beta \mathrm{a}$ - slope of the anodic curve,

$\beta \mathrm{c}$ - slope of the cathode curve,

icor - density of corrosion current.

For the initial state the porosity of the deposited layers (P) but also the efficiency of the corrosive attack $(\mathrm{Pe})$ could be calculated.

The porosity of the layers was calculated using a relation establish by Elsener [32]:

$$
P=\left(\frac{R_{p s}}{R_{p}}\right) x 10^{-\frac{\left|\Delta E_{i=0}\right|}{b_{a}}}
$$

where:

Rps - polarization resistance of the substrate,

$\mathrm{Rp}$ - polarization resistance of the layer,

$\Delta \mathrm{Ei}=0$ - the difference between the values of the corrosion potentials of the substrate and the layer, $\beta a-$ the anodic Tafel slope of the curve for the substrate.

The protection against corrosive attack was calculated using the relation:

where:

$$
P_{\mathrm{e}}=\left(1-\frac{i_{\text {cor,coating }}}{i_{\text {cor,substrate }}}\right) \cdot 100
$$

$\mathrm{i}_{\text {cor,coating }}$ - density of corrosion current of the coating,

$\mathrm{i}_{\text {cor,substrate }}$ - density of corrosion current of the substrate,

Table 4 presents the main parameters of the electrochemical corrosion process obtained in the tests carried out in $3.5 \% \mathrm{NaCl}$ solution.

Table 4. The main electrochemical parameters of the corrosion process

\begin{tabular}{|c|c|c|c|c|c|c|c|c|c|}
\hline $\begin{array}{c}\text { Nr. } \\
\text { crt. }\end{array}$ & Sample & $\begin{array}{c}\mathbf{E}_{\text {oc }} \\
(\mathrm{mV})\end{array}$ & $\begin{array}{c}\mathbf{E}_{\text {cor }} \\
(\mathrm{mV})\end{array}$ & $\begin{array}{c}\mathbf{i}_{\text {cor }} \\
\left(\mu \mathrm{A} / \mathrm{cm}^{2}\right)\end{array}$ & $\begin{array}{c}\boldsymbol{\beta}_{\mathbf{c}} \\
(\mathrm{mV} / \text { decade })\end{array}$ & $\begin{array}{c}\boldsymbol{\beta}_{\mathbf{s}} \\
(\mathrm{mV} / \text { decade })\end{array}$ & $\begin{array}{c}\mathbf{R}_{\mathrm{p}} \\
\left(\mathrm{k} \Omega \times \mathrm{xcm}^{2}\right)\end{array}$ & $\begin{array}{c}\mathbf{P} \\
(\%)\end{array}$ & $\begin{array}{c}\mathbf{P}_{\mathbf{o}} \\
(\%)\end{array}$ \\
\hline 1. & $\mathrm{C} 45$ & -685 & -578 & 0.608 & 1081 & 33 & 23.11 & - & - \\
\hline 2. & $\mathrm{M} 81 \mathrm{NS}$ & -593 & -554 & 4.716 & 452 & 70 & 5.59 & 2.01 & negative value \\
\hline 3. & $\mathrm{M} 130$ & $\mathbf{- 5 6 4}$ & $\mathbf{- 5 4 5}$ & $\mathbf{0 . 4 6 2}$ & 708 & 186 & $\mathbf{1 3 8 . 6 8}$ & $\mathbf{0 . 0 6}$ & $\mathbf{2 4 . 0 3}$ \\
\hline 4. & $\mathrm{M} 136 \mathrm{~F}$ & -625 & -601 & 5.301 & 575 & 51 & 3.84 & 2.92 & negative value \\
\hline
\end{tabular}

The variations of the open circuit potential (Eoc) are shown in Figure 2 and the Tafel curves corresponding to the tested samples are shown in Figure 3. 


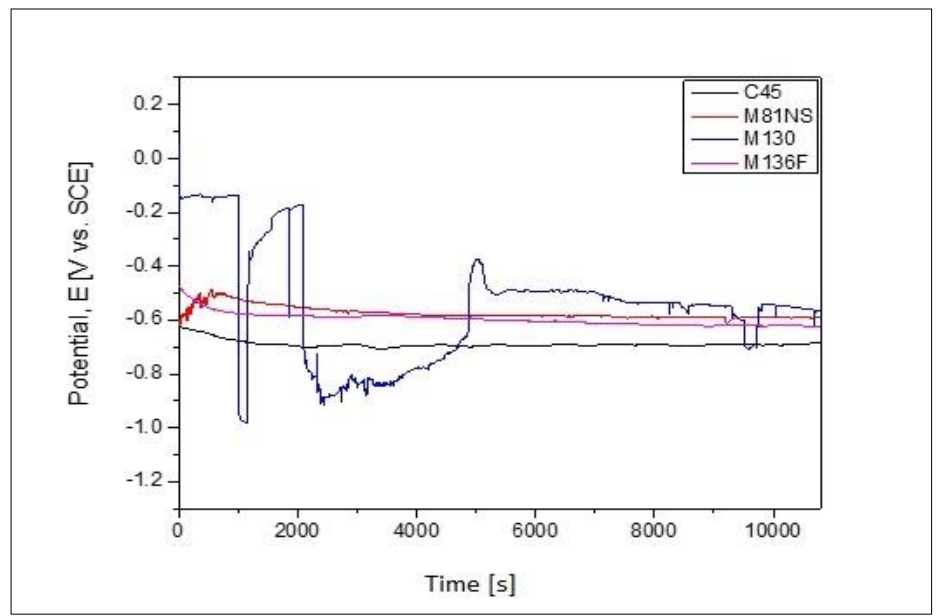

Figure 2. Evolution of the open-circuit potential (Eoc) for all investigated samples

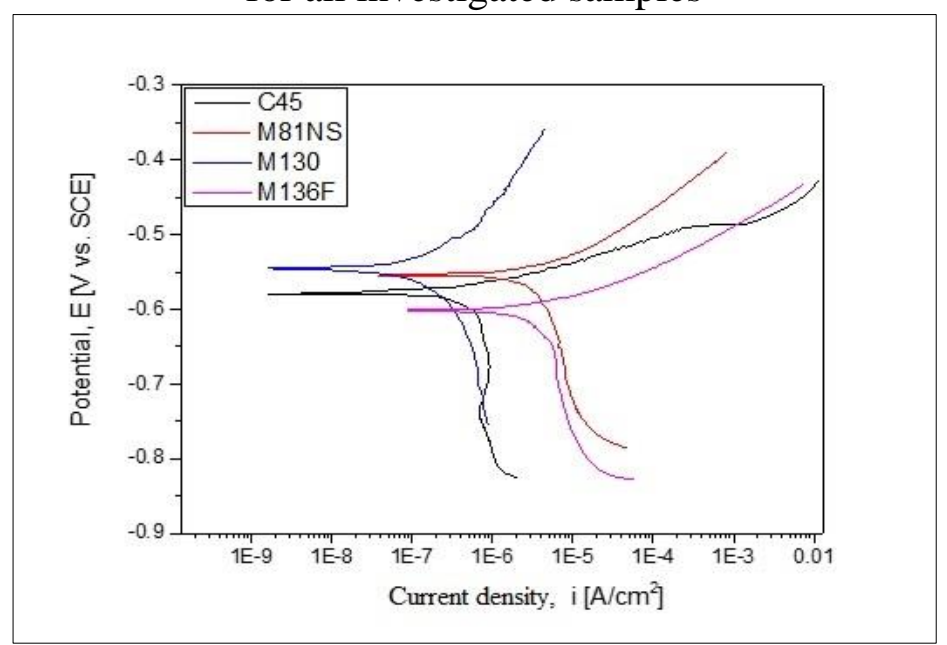

Figure 3. Tafel curves of all investigated samples

If we consider the value of the corrosion potential (Ecor), the values of the more electropositive Ecor corrosion potential are considered to have a better corrosion behavior.

From this point of view it is observed that the highest positive value $(-545 \mathrm{mV})$ is that of the sample M130 meaning a better corrosion behavior in the electrolyte used.

It is known that a low corrosion current density (icor) indicates good corrosion resistance. Thus, if we consider this criterion, it is observed that the deposition used for the M130 sample records the lowest value (462 $\left.\mathrm{nA} / \mathrm{cm}^{2}\right)$, demonstrating that it has a better corrosion resistance to the support material (sample C45) but also to the other types. of coatings.

If we analyze the corrosion behavior according to the value of the open circuit potential (Eoc), we must take into account the fact that the more electropositive values denote a better corrosion behavior. In the case of the samples covered with Metco $81 \mathrm{NS}$, Metco 136F and in the case of the basic material (C45), it is observed that the evolution of the potential is relatively constant, unlike the specimens sprayed with Metco 130 which have a fluctuating evolution in the first part of the considered test (first $4500 \mathrm{~s}$ ). The average value of the potential in the open circuit, showed that the sample M130 has the most electropositive potential $(-564 \mathrm{mV})$ and consequently a nobler character from the electrochemical point of view. It is known that a high value polarization resistance $(\mathrm{Rp})$ shows a good corrosion behavior of a material, and a low value of this parameter represents a lower corrosion resistance. Thus, from the values resulting from the corrosion test it is observed that the higher value is that of the sample M130 $\left(138.68 \mathrm{k} \Omega \mathrm{xcm}^{2}\right)$, so this is characterized by a better resistance to corrosion compared to the other samples analyzed. 
From the point of view of the porosity values of the layers $(\mathrm{P})$ calculated on the basis of the obtained electrochemical parameters, the sample M130 with a value of only $0.06 \%$ is highlighted. Taking into account the efficiency of the corrosive attack $(\mathrm{Pe})$ it is observed that the entire sample M130 is noted with a value of $24.03 \%$.

Comparing the values of the electrochemical parameters corresponding to the coated samples and the uncoated material (substrate) it can be said that the M130 sample has the best corrosion resistance in the $3.5 \% \mathrm{NaCl}$ solution with the best values of the electrochemical parameters. The results obtained from the corrosion test were supplemented by observations of the morphology of the sample surfaces, both in the initial state and after performing the tests.

\section{Discussion SEM measurments}

The morphological changes were interpreted comparatively between the two states, so that the effect of the corrosion environment on the surface quality can be highlighted.

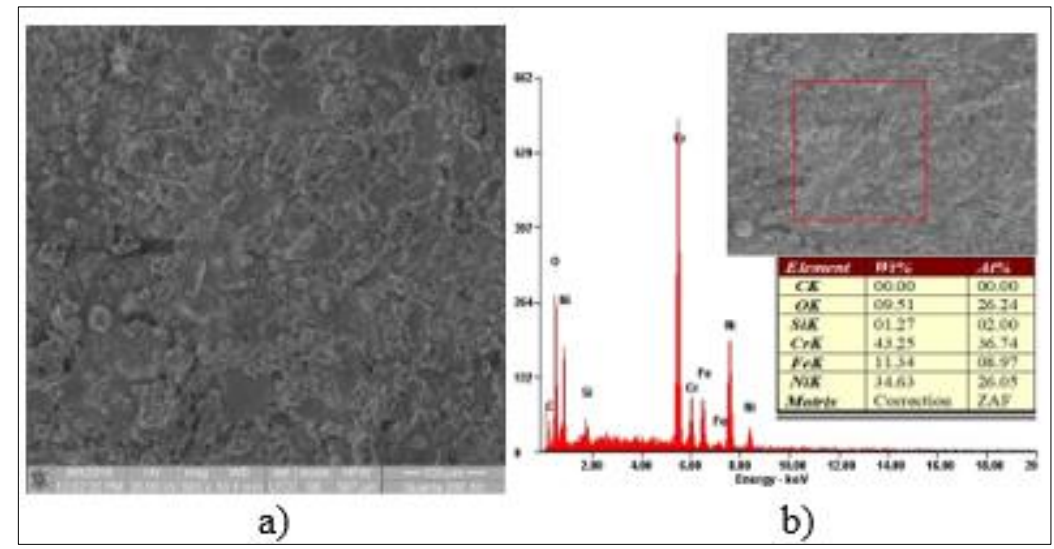

Figure 4. a) SEM image of the coating deposited with Metco 81NS before corrosion $(500 \mathrm{X})$, b) Elemental chemical analysis of the coating deposited with Metco 81NS, before corrosion

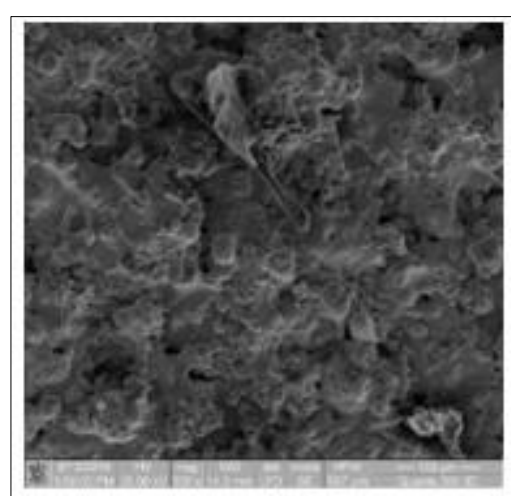

a)

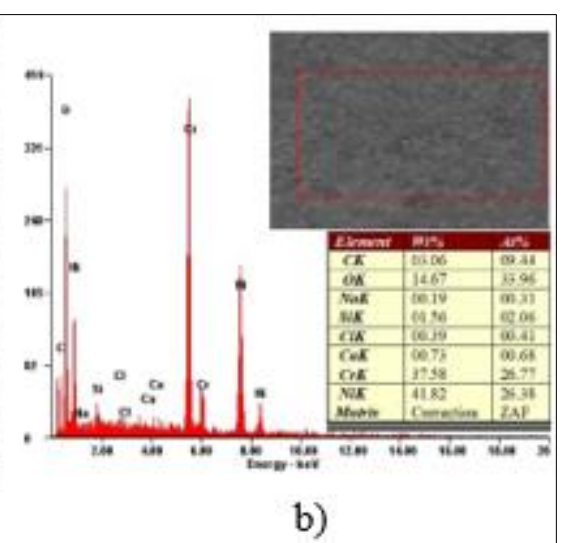

b)

Figure 5. a) SEM image of the coating deposited with Metco 81NS after corrosion (500X), b) Elemental chemical analysis of the coating deposited with Metco 81NS after corrosion

Figures 4 and 5 respectively show images of the surface of the layer deposited with Metco 81NS powder before and after corrosion together with the results of elemental chemical analyzes of type EDS (Energy Dispersive X-Ray Spectroscopy) made on the surfaces of the two samples. In the case of the sample in the initial state, the specific chemical composition is observed, in which the elements $\mathrm{Cr}$ (43.25 wt $\%)$, Ni (34.6 wt\%), Fe (11.34 wt\%) are present in higher percentages, O (9.51 wt \%), Si (1.27 wt $\%)$. 


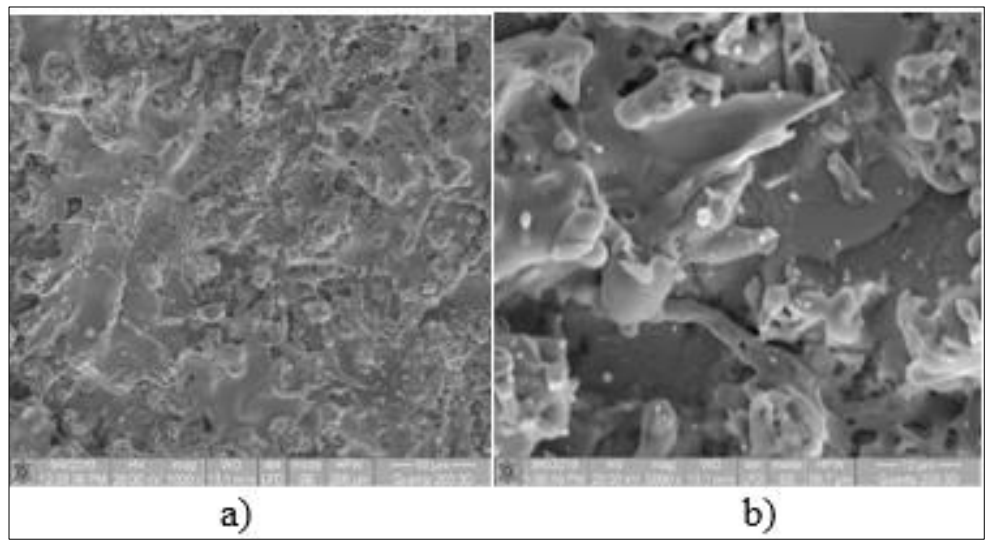

Figure 6. SEM images of the coating deposited with Metco 81NS, before the corrosion test: a) 1000X, b) 5000X

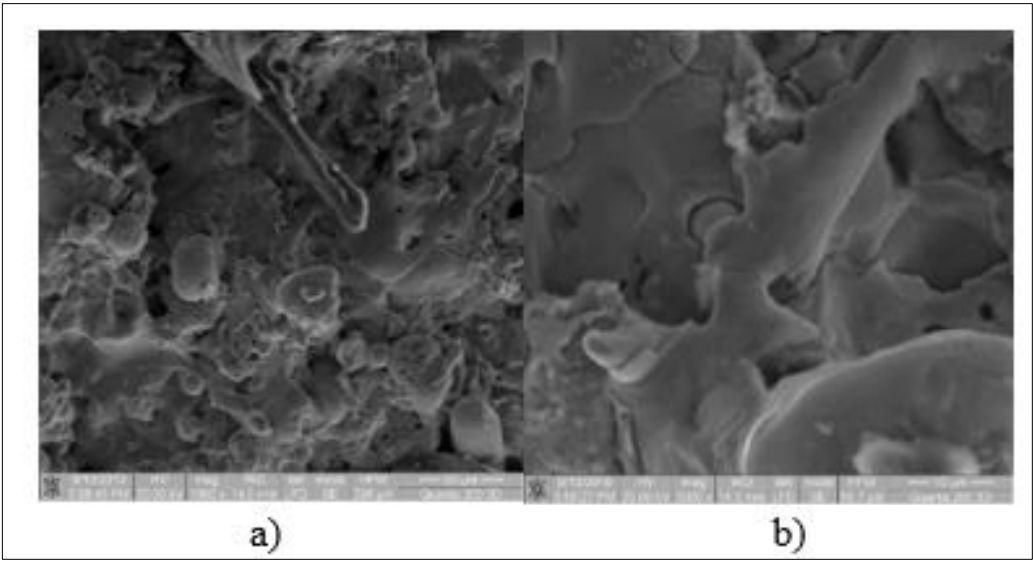

Figure 7. SEM images of the coating deposited with Metco 81NS, after the corrosion test: a) $1000 \mathrm{X}$, b) $5000 \mathrm{X}$

In the case of the same coating, after the application of the resistance test to corrosion, it is observed, besides the presence of elements specific to the type of layer and the presence of elements specific to the environment of corrosion (which are in very small percentages): $\mathrm{Cr}(37.58 \mathrm{wt} \%), \mathrm{Ni}(41.82 \mathrm{wt} \%), \mathrm{O}$ (14.67 wt \%), Si (1.56 wt \%), Ca $(0.73 \mathrm{wt} \%), \mathrm{Cl}(0.39 \mathrm{wt} \%), \mathrm{Na}(0.19 \mathrm{wt} \%)$. The fact that the mass ratios of the component chemical elements have not undergone major changes, denotes that the coating has a stable character and was not decisively influenced by the $3.5 \% \mathrm{NaCl}$ electrolyte solution.

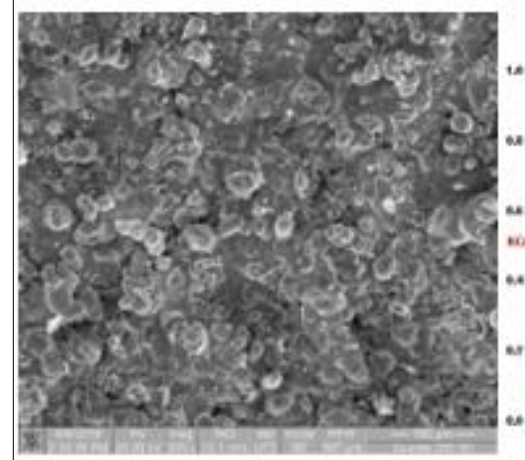

a)

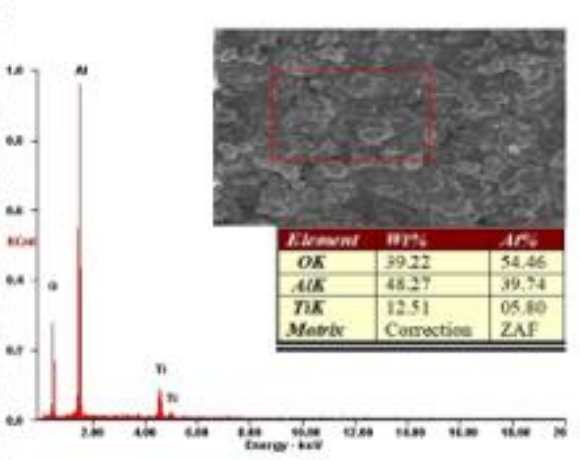

b)

Figure 8. a) SEM image of the coating deposited with Metco 130 before corrosion, $(500 \mathrm{X})$, b) Elemental chemical analysis of the coating deposited with Metco 130 


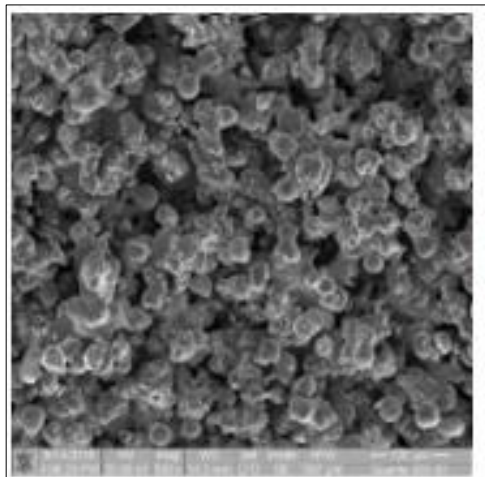

a)

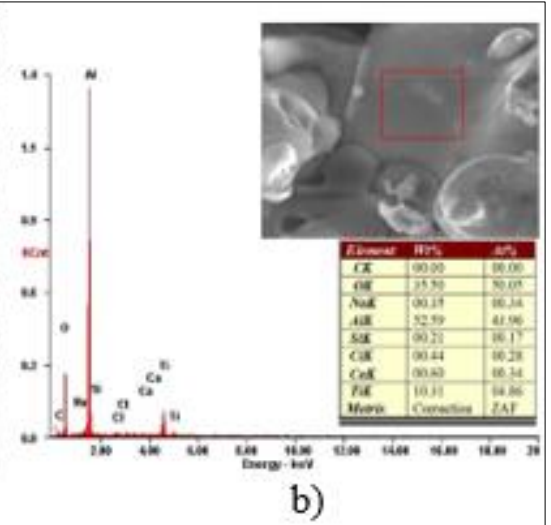

b)

Figure 9. a) SEM image of the coating deposited with Metco 130 after corrosion, (500X), b) Elemental chemical analysis of the coating deposited with Metco 130

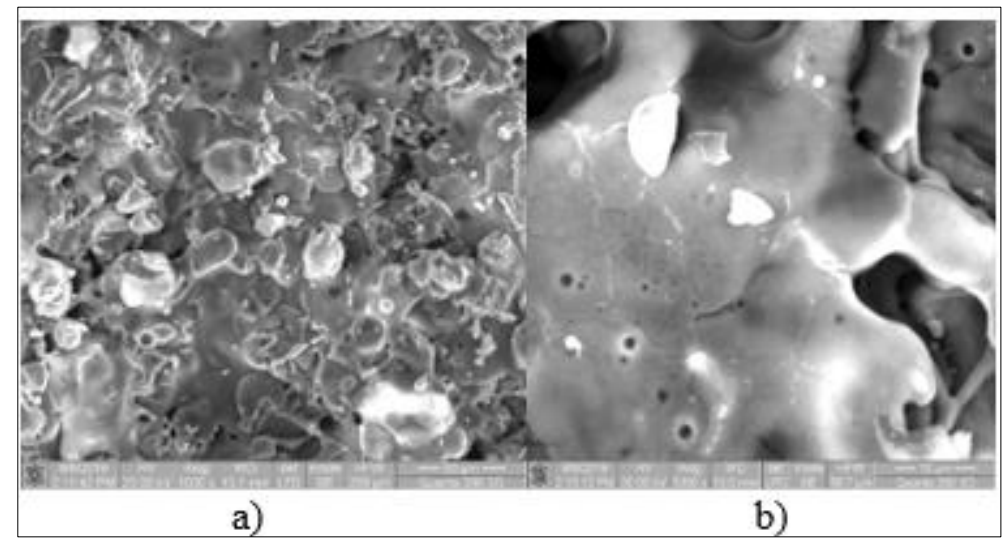

Figure 10. SEM images of the coating deposited with Metco 130, before the corrosion test: a) 1000X, b) 5000X

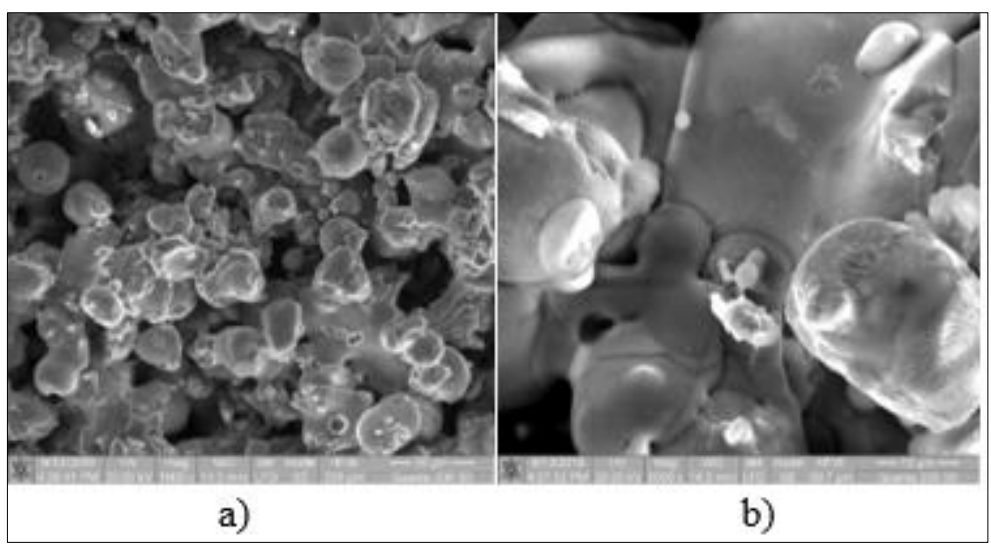

Figure 11. SEM images of the coating deposited with Metco 130, after the corrosion test: a) 1000X, b) 5000X

Analyzing similar the sprayed layer with Metco 130 (Figures 8-11), we can say that there have been no substantial changes in its structure, following exposure to corrosive environment.

Following the elemental chemical analysis and the comparative evaluation between the starylline before and after the corrosion test (Figures 8 and 9), the presence of the chemical elements specific to 
the corrosive substance was observed, their weights relative to those recorded in the case of Metco 81NS coating being similar.

By strictly analyzing the morphology of the surface of the coating made with Metco 130 after corrosion (Figure 11), compared with the appearance before corrosion (Figure 11), we can observe that there was a slight accentuation of the gaps between the splats, with slight highlighting of some particles, which does not seem to negatively influence the corrosion resistance confirmed by the process records.

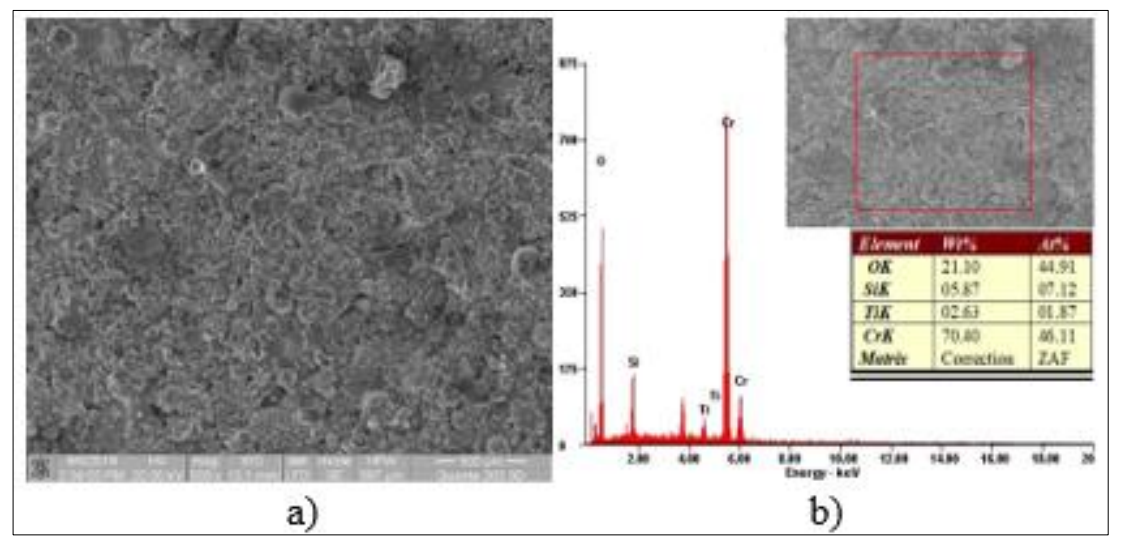

Figure 12. a) SEM image of the coating deposited with Metco 136F before corrosion, (500X), b) Elemental chemical analysis of the coating deposited with Metco 136F

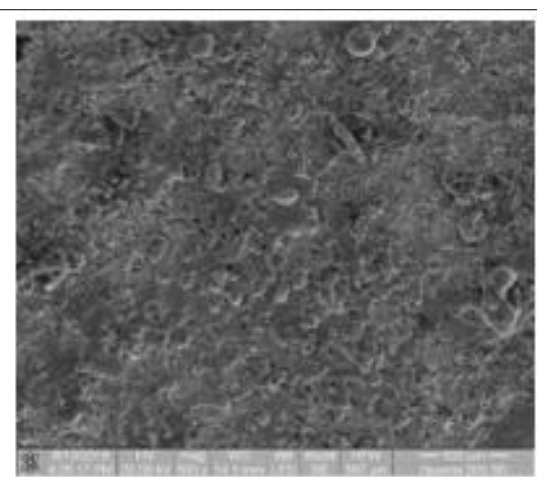

a)

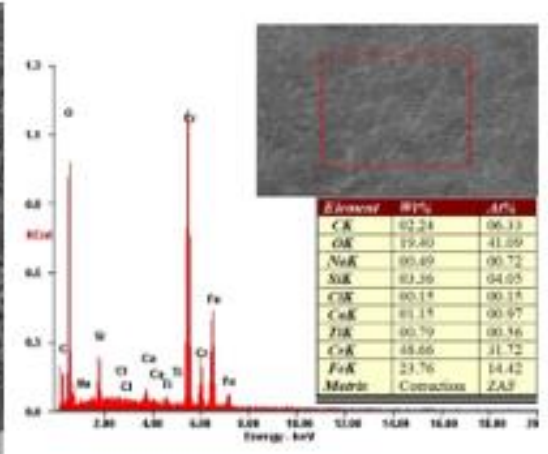

b)

Figure 13. a) SEM image of the coating deposited with Metco 136F after corrosion, (500X), b) Elemental chemical analysis of the coating deposited with Metco 136F

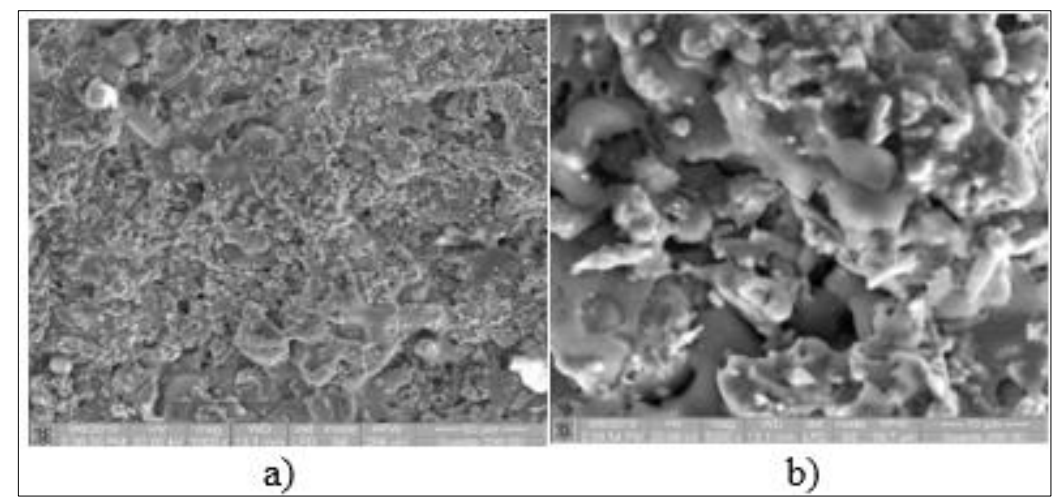

Figure 14. SEM images of the coating deposited with Metco 136F, before the corrosion test: a) 1000X, b) 5000X 


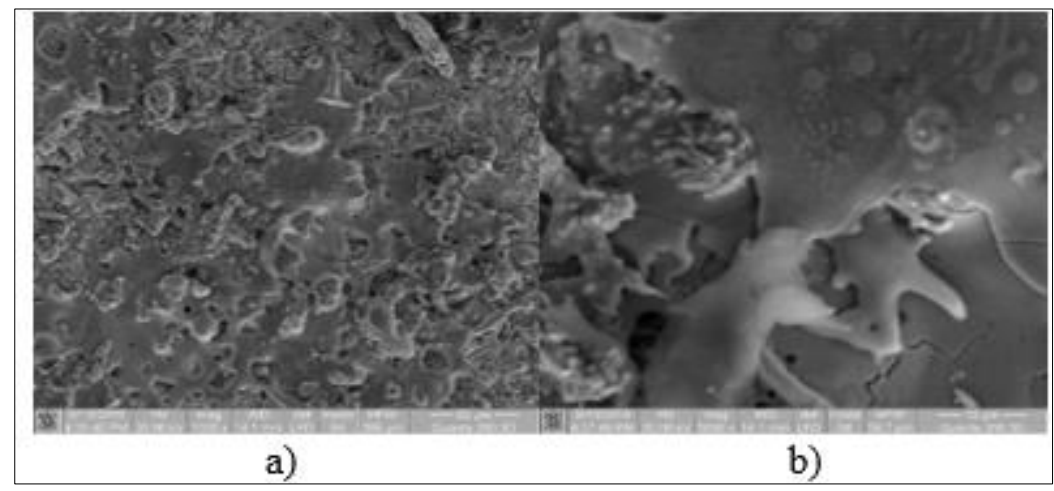

Figure 15. SEM images of the coating deposited with

Metco 136 F, after the corrosion test: a) 1000X, b) 5000X

When comparing the elemental chemical composition of the surface of the layer obtained by spraying the Metco $136 \mathrm{~F}$ powder for the cases before and after the corrosion test (Figures 12, 13), the presence of some chemical elements generated during the corrosion process was observed, in very small percentages: $\mathrm{C}(2.24 \mathrm{wt} \%), \mathrm{Na}(0.49 \mathrm{wt} \%), \mathrm{Cl}(0.15 \mathrm{wt} \%), \mathrm{Ca}(1.15 \mathrm{wt} \%)$. Comparing morphologically the appearance of the surface in the initial state with that of the corroded state, we can say that no major structural changes are observed, the layer having the same lamellar aspect specific to the coatings obtained by thermal spraying.

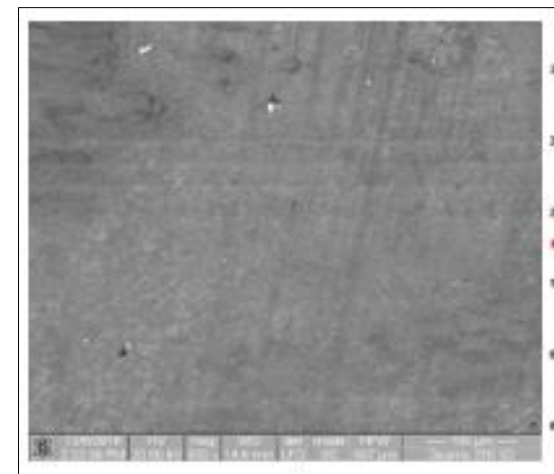

a)

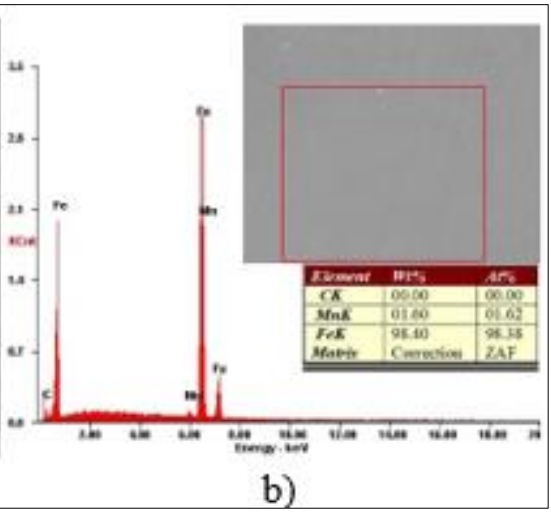

b)

Figure 16. Elemental EDS chemical analysis of the C45 core material specimen before the corrosion test

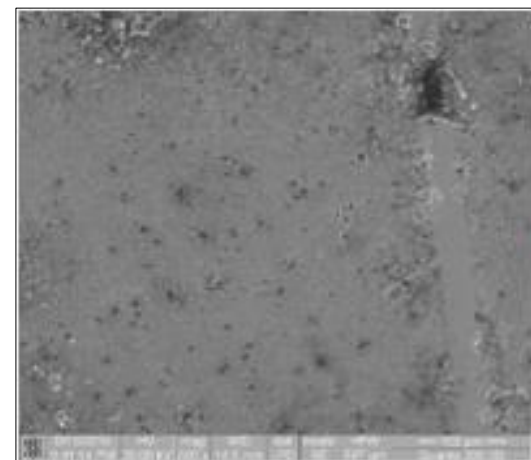

a)

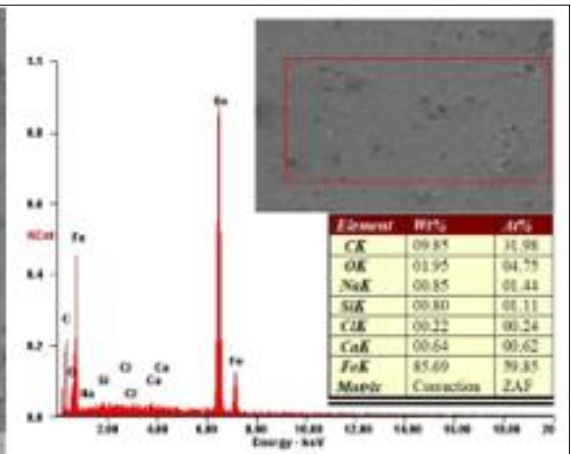

b)

Figure 17. Elemental EDS chemical analysis of the C45 core material specimen following the corrosion test 


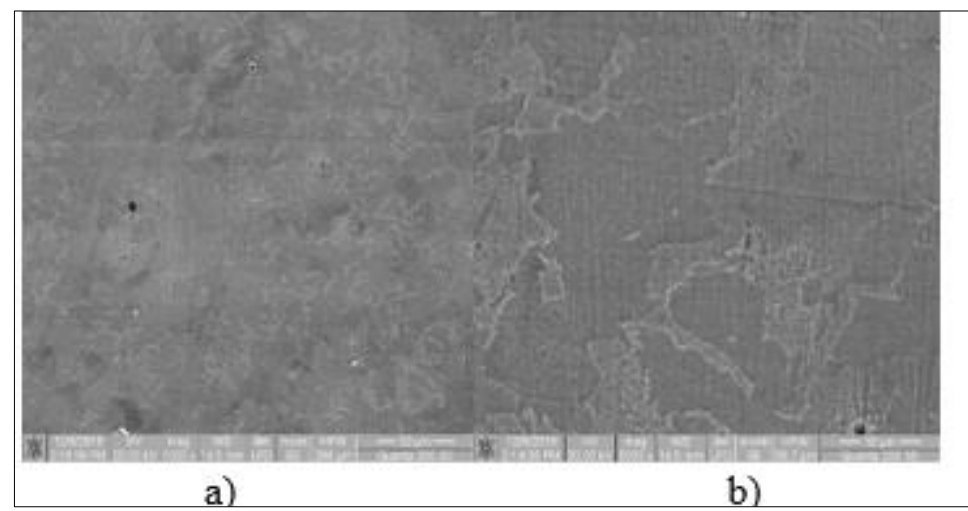

Figure 18. SEM images of the samples from the basic material C45, before the corrosion test: a) 1000X, b) 5000X

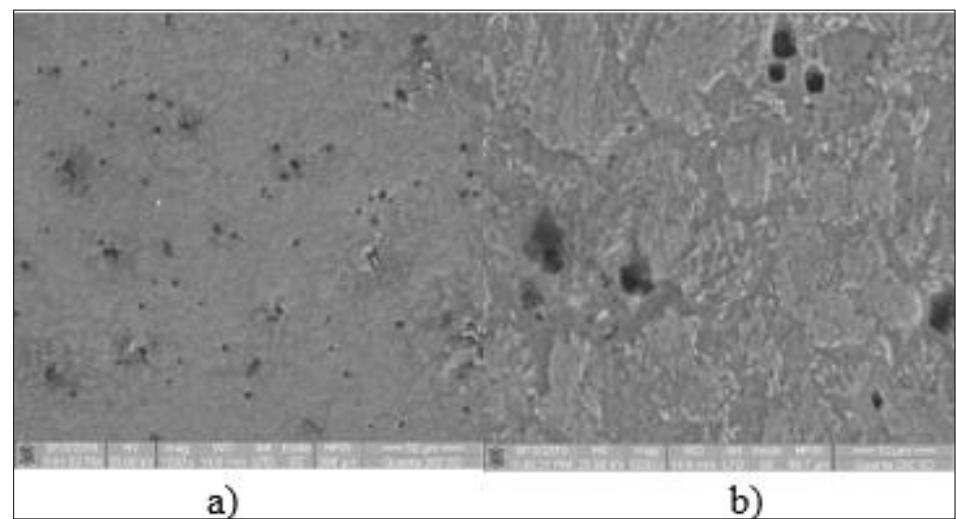

Figure 19. SEM images of the samples from the basic material C45, subjected to the corrosion test: a) 1000X, b) $5000 \mathrm{X}$

In Figures 17 and 19, the sample appearance of basic material C45 was observed, after the corrosion test was applied. Compared with the appearance of the samples in the initial state (Figure 18), it is observed that on the surface of the sample there are small pitting corrosion points, the elemental chemical analysis of EDS type performed on the surface of the sample (Figure 16), highlighting the presence in very small quantities of some chemical elements specific to the interaction with the corrosion medium ( $\mathrm{Ca}, \mathrm{Cl}, \mathrm{Si}, \mathrm{Na}, \mathrm{O})$.

\section{Conclusions}

Based on the potential values of Eoc and Ecor, it is observed that the coating of the steel substrate with layers deposited by thermal spraying has led to an improvement of its behavior to corrosion, which comes in support of the extension of the life of the shaft and bearing shafts of the crankshafts through thermal spray.

The appearance of the control sample (the uncoated basic material) observed when analyzing the surface after the corrosion test is carried out is characterized by the presence of corrosion points, while the surfaces deposited by thermal spraying of the three types of powders analyzed (Metco $81 \mathrm{NS}-\mathrm{Cr}_{3} \mathrm{C}_{2}$ (Ni20Cr), Metco $130-\mathrm{Al}_{2} \mathrm{O}_{3} 13 \mathrm{TiO}_{2}$, Metco $136 \mathrm{~F}-\mathrm{Cr}_{2} \mathrm{O}_{3} \mathrm{SiO}_{2} \mathrm{TiO}_{2}$ ) were not significantly affected by the corrosive agent.

Comparing the values of the electrochemical parameters corresponding to the coated samples with those obtained in the case of the uncoated material (substrate) it can be said that the sample M130 (layer made by depositing powder $\mathrm{Al}_{2} \mathrm{O}_{3} 13 \mathrm{TiO}_{2}$ ) has the best corrosion resistance in the $3.5 \% \mathrm{NaCl}$ solution with the best values of the electrochemical parameters: the noblest electrochemical character, the most electropositive potential of corrosion, the lowest density of the corrosion current and the highest value of the polarization resistance. 


\section{References}

1.CZERWINSKI, F., Thermochemical Treatment of Metals, Chapter 5 in: Heat Treatment Conventional and Novel Applications, InTech Open, Rijeka, 2012, p. 73-112

2.BEARDSLEY, M.B., HAPPOLDT, P.G., KELLEY, K.C., Thermal Barrier Coatings for Low Emission, High Efficiency Diesel Engine Applications- SAE International 1999-01-2255.April 26-28, 1999.

3. AHANGARANI, S.H., MAHBOUBI, F., SABOUR, A.R., Effects of various nitriding parameters on active screen plasma nitriding behavior of a low-alloy steel, Vacuum 80 (2006) 1032

4. SATHISH, S., GEETHA M., Comparative study on corrosion behavior of plasma sprayed Al2O3, $\mathrm{ZrO} 2, \mathrm{Al} 2 \mathrm{O} 3 / \mathrm{ZrO} 2$ and ZrO2/A12O3 coatings, Trans. Nonferrous Met. Soc. China 26(2016) 1336-1344 5. RAO, K.V.S., TEJASWINI, G.C., GIRISHA, K.G., Corrosion Behavior of Plasma Sprayed Cr2O3 Al2O3 - ZrO2 multilayer coatings on mild steel, Materials Today: Proceedings, 5, (2018) 24068-24074 6. XIA, D.H., SONG, S., WANG, J., BI., H., JIANG, Y., HAN Z., Corrosion behavior of tinplate in $\mathrm{NaCl}$ solution, Trans. Nonferrous Met. Soc. China, 22, 2012, 717-724

7. LI, Y., WANG, X., ZHANG, G., Corrosion behaviour of $13 \mathrm{Cr}$ stainless steel under stress and crevice in 3.5 wt.\% NaCl solution, Corrosion Science, 163,2019, 108290

8. SINGH, A.A.M.M., FRANCO, P.A., BINOJ, J.S., Enhancement of corrosion resistance on plasma spray coated mild steel substrate exposed to marine environment, Materials Today: Proceedings 15 (1), 2019, 84-89

9. LINDGREN, M., HUTTUNEN-SAARIVIRTA, E., PELTOLA, H., ROMU, J., SARIKKA, T., HANINNEN, H., POHJANNE, P., Crevice corrosion of stainless steels 904L, 2205 and 2507 in hightemperature sulfuric acid solution containing chlorides: Influence of metal cations, Corrosion, 74(2), 2018, 225-240

10. KUMAR, A., NAYAK, S.K., BIJALWAN, P., DUTTA, M., BANERJEE, A., LAHA, T., Optimization of mechanical and corrosion properties of plasma sprayed low chromium

containing Fe-based amorphous/nanocrystalline composite coating, Surface \& Coatings Technology 370 (2019) 255-268

11. BIJALWAN, P., KUMAR, A., NAYAK, S.K., BANERJEE, A., DUTTA, M., LAHA, T., Microstructure and corrosion behavior of Fe-based amorphous composite coatings developed by atmospheric plasma spraying, Journal of Alloys and Compounds 796 (2019) 47e54

12. MAHU, G., MUNTEANU, C., ISTRATE, B., BENCHEA, M., LUPESCU, S., Influence of Al2O3$13 \mathrm{TiO} 2$ powder on a $\mathrm{C} 45$ steel using atmospheric plasma spray process, IOP Conf. Ser.: Mater. Sci. Eng., 444(3), 2018, 032010

13. MAHU, G., MUNTEANU, C., ISTRATE, B., BENCHEA, M. , Analysis of plasma jet depositions on a C45 steel used in crankshaft manufacturing, in: Powder Metallurgy and Advanced Materials RoPM\&AM 2017, Book Series: Materials Research Proceedings, Vol. 8, 2018, 61-69

14. MAHU, G., MUNTEANU, C., ISTRATE, B., BENCHEA, M., Plasma sprayed coatings on crankshaft used steels, IOP Conf. Ser.: Mater. Sci. Eng., 227, 2017, 012077

15. BARCA, E.S., MAHU, G., VLADU, M. R., ABRUDEANU, M., MUNTEANU, C., Analysis of the influence of working temperature on stress distribution in case of piston with A12O3 deposited layer, Tehnomus J., 22, 2015, 446-451

16.BARCA, E.S., VLADU, M.R., MAHU, G., ABRUDEANU, M., MUNTEANU, C., Stress distribution for a piston with a $\mathrm{ZrO} 2 / 20 \%$ Y2O3 top layer deposited on the piston heads which absorbs gas pressure, Tehnomus J., 22, 2015, 457-461

17. ASHRAFUL, A.M., MAJUSKI, H.H, KALAM, M.A., RASHEDUL, H.K., SAJJAD, H., ABEDIN, M.J., Influence of anti-corrosion additive on the performance, emission and engine component wear characteristics of an IDI diesel engine fueled with palm biodiesel, Energy Conversion and Management 87 (2014) 48-57 
18. HASANNUDDIN, A. K., WIRA, J. Y., SARAH, S., WAN SYADITUL AQMA, W. M. N., ABDUL HADI, A.R., HIROFUMI, N., AIZAM, S.A., AIMAN, M.A.B., WATANABE, S., AHMAD, M.I., AZRIN, M.A., Performance, emissions and lubricant oil analysis of diesel engine running on emulsion fuel, Energy Conversion and Management 117 (2016) 548-557

19. RAPOSO, H., TORRES FARINHA, J., FONSECA, I., GALAR, D., Predicting condition based on oil analysis - A case study, Tribology International 135 (2019) 65-74

20. DAVIS, D., SHAH, F.A., PANIGRAHI, B., SINGH, S., Effect of Cr2AlC nanolamella addition on tribological properties of 5W-30 engine oil, Applied Surface Science 493 (2019) 1098-1105

21. TSUCHIYA, T., SHIOTANI, H., GOTO, S., SUGIYAMA, G., MAEDA, A., Japanese standards for diesel fuel containing 5\% FAME: investigation of acid generation in FAME blended diesel fuels and its impact on corrosion, SAE Techn. Paper 2006-01-3303, 2006, 6-22

22. PEREIRA, F.M, VELASQUEZ, J. A., RIECHI, J.L., TEIXERIA, J., RONCONI, L.,RIOLFI, S.JR., KARAS, É.L., ABREU, R.A., TRAVAIN, J., Impact of pure biodiesel fuel on the service life of enginelubricant: A case study, Fuel 261 (2020) 116418

23. TORMOS, B., NOVELLA, R., GOMEZ SORIANO, J., GARCIA, B., NAOHIDE, T., UEHARA, I., ALONSO, M., Study of the influence of emission control strategies on the soot content andfuel dilution in engine oil, Tribology International 136 (2019) 285-298

24. BESSER, C., STEINSCUTZ, K., DORR, N.N., FARKAS, F.N., ALLMAIER, G., Impact of engine oil degradation on wear and corrosion caused by acetic acid evaluated by chassis dynamometer bench tests, Wear317(2014)64-76

25. KARDOŠ, S., PIETRIKOVÁ, S., Evaluation of motor oil characteristics and degradation factors for possibilities of continuous diagnostics, Acta Electrotechnica et Informatica, 16(2), 2016, 20-24

26. YANG, Y. Z., JIANG, Y. M., Li J., In situ investigation of crevice corrosion on UNS S32101 duplex stainless steel in sodium chloride solution, Corrosion Science 76 (2013) 163-169

27. KAMENEVA, A., KICHIGIN, V., LOBOV, N., KAMENEVA, N., Data on the effect of structure, elemental and phase composition gradient of nitride multilayer coatings on corrosion protection of different substrates in $3 \% \mathrm{NaCl}$ and $5 \% \mathrm{NaOH}$ solutions, Applied Surface Science, Vol.489, 165-174, 2019

28. ROSTEK, E., BABIAK, M., The experimental analysis of engine oil degradation utilizing selected thermo-analytical methods, Transportation Research Procedia 40 (2019) 82-89

29. CHICET, D., TUFESCU, A., PAUlin, C., PANȚURU, M., MUNTEANU, C., The Simulation of Point Contact Stress State for APS Coatings, IOP Conference Series: Materials Science and Engineering, 209 (1), 2017, 012044.

30. PANȚURU, M., CÂRLESCU, V., CHICET, D., RĂILEANU, L., MUNTEANU, C., Evaluation of adhesion - cohesion of some TBCs used for internal combustion engine valves using scratch method, UPB Scientific Bulletin, Series B: Chemistry and Materials Science, 81, (2), 2019, 215-224,

31. PANȚURU, M., CHICET, D., LUPESCU, Ş., ISTRATE, B., MUNTEANU, C., Applications of ceramic coatings as TBCs on the internal combustion engine valves, ACTA TECHNICA NAPOCENSIS, Series: Applied Mathematics, Mechanics, and Engineering, 61, (I), 2018.

32. ELSENER, B., ROTA, A., BOHNI, H., Impedance study on the corrosion of PVD and CVD titanium nitride coatings, Mater. Sci. Forum 44-45 (1989) 29-38,

http://dx.doi. org/10.4028/www.scientific.net/MSF.44-45.29.

Manuscript received: 9.06 .2020 